\title{
Ladakh Traditional Farming: An Approach to Resource Utilization under Changing Climate
}

\author{
M.S. Raghuvanshi ${ }^{1 *}$, Ngawang Dorjay ${ }^{2}$, R.K. Singh ${ }^{3}$, B.L. Manjunatha ${ }^{3}$, \\ P.C. Moharana ${ }^{3}$, Enoch Spalbar ${ }^{2}$, Stanzin, Landol ${ }^{2}$ and Anurag Saxena ${ }^{3}$ \\ ${ }^{1}$ National Bureau of Soil Survey and Land Use Planning, Nagpur-440033, India \\ ${ }^{2}$ Regional Research Station, Central Arid Zone Research Institute, Leh-Ladakh 194101, India \\ ${ }^{3}$ Central Arid Zone Research Institute, Jodhpur-342003, India \\ *Corresponding author
}

\section{A B S T R A C T}

\section{Keywords}

Ladakh traditional

farming, Social

structure,

Agricultural system

Article Info

Accepted:

04 August 2019

Available Online:

10 September 2019
Ladakh short agricultural season of 6-7 months in the lap of Himalayas and its production was high and enough to feed the entire population with traditional techniques to suit the local climatic conditions along with strong social structure to support the agricultural system. Today it faces many climatic challenges in more ways than one such as receding glacial snow, unusual rainfall, floods, changing weather patterns resulting infiltration of new pests and consequently and significantly changed the lifestyle of high altitude cold arid Ladakh. But an approach to resource utilization is patterned in present scenario diminishing the traditional identity with increasingly changing infrastructures due to climate change.

\section{Introduction}

Ladakh, also known as "Little Tibet", is a wildly beautiful desert region high in the Western Himalayas, at altitudes ranging from 10,000 to 14,000 feet (from 3,000 to $4,300 \mathrm{~m}$ ). It is a place of limited resources with an extreme climate. The Himalayan mountain range has significant bearing on the climate of India, as its towering height created a vast rain-shadow zone in the north. The cold dry tracts of the zone referred to as cold arid region, spread over in the northern states of India. The cold dry tracts of this zone referred as the cold arid region are spread over in the northern states of Jammu and Kashmir (Leh and Kargil districts), Himachal Pradesh (Lahaul-Spiti, Kinnaur and parts of Chamba district), Uttarakhand (parts of Uttarkashi, Chamoli and Pithoragarh districts) and Sikkim (barren and desolate northern tip). Ladakh lies between $32^{\circ} 15^{\prime}-36^{\circ} \mathrm{N}$ and $75^{\circ} 15^{\prime}-80^{\circ} 15^{\prime}$ $\mathrm{E}$, and is a high altitude cold arid region of India. Due to harsh winter, and heavy 
snowfall, Ladakh remains cut off for almost seven months i.e. from October - May from rest of the world by surface transportation. Ladakh being at high altitude, suffers from an extremely harsh climate during winter $\left(-30^{\circ} \mathrm{C}\right)$ and remains cut off for almost seven months i.e. from October-May from rest of the world by surface transportation. Agriculture with harvesting glacier water in the lap of Himalaya has come-up as a small-scale farming system, well adapted to this unique and extreme environment.

\section{Materials and Methods}

Keeping in view of the above features of Ladakhi agriculture, a bio-geographical survey was carried out by Regional Research Station, CAZRI, Leh during 2013-18 at different villages of Leh valley under Externally Funded Scheme National Mission on Sustaining Himalayan Ecosystem Task Force5 (Traditional Knowledge System) with the objective to find out the prevailing agricultural scenario in Leh-Ladakh in changing climate. Six villages (Saboo, $77^{0} 34^{\prime} 48^{\prime \prime}$ E, $34^{0} 0$ ' 12" N, Stakmo $\left(77^{0} 42\right.$ ' $21.56^{\prime \prime}$ E, $34^{0} 01$ ' 36.90" $\mathrm{N})$, Nang $\left(77^{0} 45^{\prime} 06.34^{\prime \prime} \mathrm{E}, 34^{0} 02\right.$ ' 35.6 " N), Umla $\left(77^{0} 23\right.$ ' $57^{\prime}$ ' E, $\left.34^{0} 14^{\prime} 12.33^{\prime \prime} \mathrm{N}\right)$, Phey $\left(77^{0} 27^{\prime} 56.99^{\prime \prime}\right.$ E, $\left.34^{0} 08^{\prime} 0.6^{\prime \prime} \mathrm{N}\right)$ and Stakna, $77^{0} 41^{\prime}$ 06.33" E, $33^{\circ}$ 59' 44.06" N) were selected for the study also to understand the pasture ecology.

\section{Results and Discussion}

\section{Growth of farming}

Region experiences mean annual precipitation of $80-300 \mathrm{~mm}$, which is scanty and negligible in the thirsty laps of mountains. Himalayan Mountains and the Indus river system are two of the gigantic land features that limit the possibility of large scale agricultural activities in Leh region. However, it is unique and representative of the Tibetan plateau. Its agriculture in the past rendered the region self- sufficient in food grains especially with small land holdings. Families rely more essentially on subsistence agriculture based on principal crops like wheat, barley and potato on their stone-built terraces. Potato, being main vegetable, is a main cash crop grown during May-September in the region. The art of crop production which is and seems as old as civilization itself and its essential features have remained largely unchanged over the ages. Productivity in cold deserts in Himachal Pradesh, as elsewhere, is centered on crops and animal husbandry.

The altitude variation affects the local climate and the temperature dips to around -40 degrees in winter, while the mean maximum temperature in summer is around 14 degrees. The region receives very little annual precipitation of $10 \mathrm{~cm}$, mainly in form of snow and has more than 320 sunny days. The solar radiation is as high as $6-7 \mathrm{kwh} / \mathrm{sq} \mathrm{m}$, which is among the highest in the world. Because of the thin atmosphere, solar radiation is quite extreme. Humidity levels range from 6-24\% making the air very dry. Agriculture and harvesting glacier water in the lap of Himalaya has developed a small-scale farming system adapted to this unique and extreme environment. Families rely essentially on subsistence agriculture based on principal crops like wheat, barley and potato. Potato, being main vegetable during winter season is a main cash crop grown during May-October in the region. The art of crop production which is as old as civilization itself and its essential features have remained largely unchanged over the ages. Productivity in cold deserts in Himachal Pradesh, as elsewhere, is centered on crops and animal husbandry. It is based on human labour, animal power and hand-made tools. Terraced fields on slopes of high mountains are irrigated with glacial meltwater and fertilised with undecomposed farmyard-manure, human "night soil" and a starter dose of fertilizers like urea, DAP and muriate of potash. Every house also has small 
vegetable garden along with small orchards of apple or apricot, and keep a few animals, such as, goats, sheep, cows and dzo (a cross between a yak and a local breed of cow). Even with such harsh climatic conditions, agriculture by almost any measure, is extremely successful. It represents a unique way of human survival and progress. Although simple, it is ecologically sustainable, and just as important, people are supported by community bonds that provide a deep sense of psychological security. Due to its simplicity and closeness to the nature, people are psychologically happy and physically fit. But with modernity setting in, the traditional structures and processes are giving way to modern styles and problems. Festival called SAKA denotes the onset of agriculture season in Ladakh around April and Dzo are honoured with chhang and barley products, as it is thought that they have full-right for these foods.

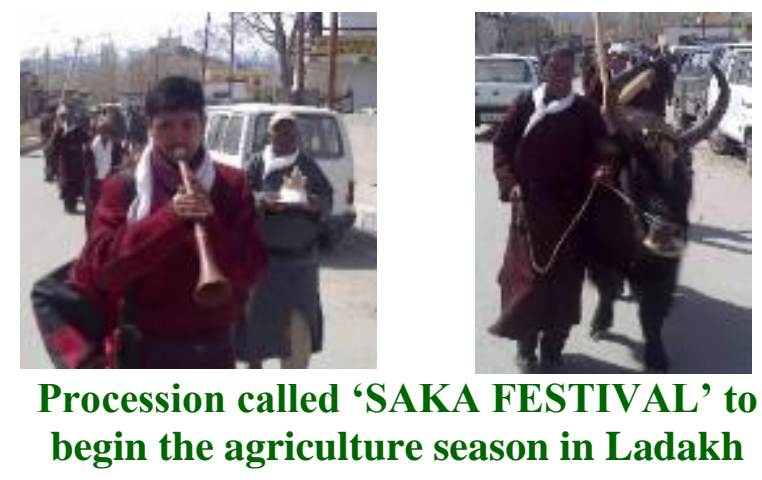

Prioritizing crop sowing is a very amazing and competitional phenomenon when all the farmers remain on the fields and women being a main stakeholders support the sowing along with folk songs. Germplasm of food crops, acclimatized to West Himalayan cold deserts, is saved and conserved year after year. The traditional germplasm used in Ladakh are nenak, yang-ma, yang-kar, sermo, tug-zur of barley, buck-suk of alfalfa, to-chen of small and big wheat, sner-mar of pea, nyas-kara of mustard, ta-wo of buck wheat are involved in folk songs revealing the sustainability of local germplasm. Since inception, conservation of old land races of cultivated plants, especially alfalfa, is of global importance. In case of fragmented land holdings, sowing is prioritized according to altitudinal zonation. This helps to tide over the rather limited growing period by synchronising harvesting, threshing and storage before the onset of winter. In this manner scarcity of labour is also coped with effective and efficient crop management. The individual farmer is thus able to attend to his fragmented land holding which are spaced over varying altitudes. In a majority of situations, land holdings are only one to two hectares, but easily sufficient. In fact, in most of the situations, only limited plains within Indus valleys are utilized for agricultural activities.

Uniform seed broadcasting with approximately higher seed rate is performed girls in cold desert areas. One handful of seed is uniformly broadcast in three to four equal lots. The quantity of seeds thrown in each lot is determined by the distance of furrows made during ploughing. It also reduces labour requirement.

Distribution of organic manure along with night soil at the rate of 20 to $25 \mathrm{~kg}$ of organic manure is scattered in the fields. This technique aims at uniform distribution of organic manure. It is reported that the quantity of manure spread is optimum for the plot of land falling in the range of seven steps taken 
by the woman. With the broadcasting of crop seeds, weeds find opportunity and become integral part of cultivated lands which not only compete for space and moisture, but also reduce the yields significantly and quality of produce. Weeding is only performed by farm women in a group only in vegetables not in wheat and barley and upto some extent in pea crop. Being an integral part with crop, weeds constitute 30 per cent biomass obtained after harvesting. In cultivated lands and vegetable lands, the commonly found weeds are Amaranthus spp. ,Avena sativa, Chenopodium album, Convolvulus arvensis, Digitaria spp, Medicago luplina, Medicago sativa, Melilotus officinalis, Polypogon monospeliensis, Setaria viridis, Trifolium repens, Polygonum convolvulus (wild buchwheat),Malva neglecta, Poa pretensis, Agropyron repens, Phragmitis spp., Cirsium arvense, Ambrosia spp., Artemesia spp. and Lolium spp. The presence of these weeds in a crop like potato or cereals is noted to reduce crop yield by $30-40$ per cent. In Changthang and similar pastoral ecosystems, being natural rangeland for nomadic livestock economyare under the major threat with weedy species like Cirsium arvense. It has been noted from the record that in an area like changthang, stone called shangma is used for weed control because it seems to possess toxic properties. Pieces of stones are spread over a small heap of soil, in the middle of fields in the month of December. This soluble stone, when mildly

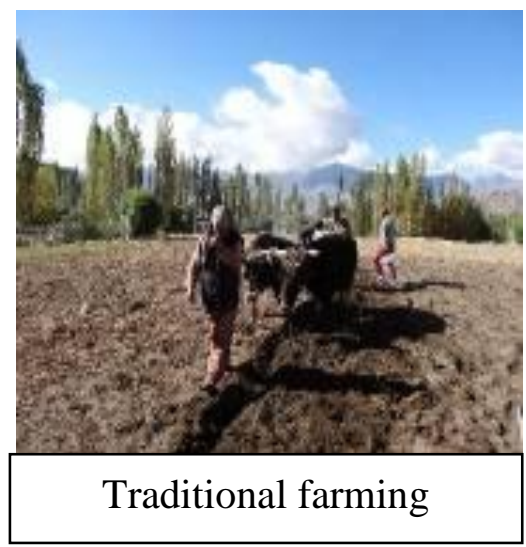

irrigated, percolates into the field. This part of weed control is being investigated. Most people now use chemical fertilizers and some kinds of technology to grow food. Institutes like State Department of Agriculture (SDA), DIHAR, CAZRI, and other institutes are supporting farmers with new varieties and fruit saplings. Out of these institutes, SDA plays an important role in maintaining cohesive relations with farmers and other line departments. Traditional crops replaced by cash crops leading to loss of agro-biodiversity, resulting in increased vulnerability to climatic \& market changes, reduction of high altitude pastoral lands due to changing climate (CC) and infiltration of weedy species like Cirsium arvense, reducing capacity to produce food on small/ marginal land holdings with increased insects and diseases and labour cost, all four dimensions of food security are predicted to be affected by climate change: food availability, food accessibility, food utilization and food system stability and increasing temperatures resulted in shifting of growing seasons, for example, attack of insects in crops and orchards of cold arid region like attack of codling moth on apple in Ladakh as a whole and tent caterpillars on apricot orchards of Dha-Biama- a serious issue of global warming are the key issues in Ladakh region, Northern India, proves as a suitable case study to investigate the effects of such dynamic conditions on food security in high altitude areas.

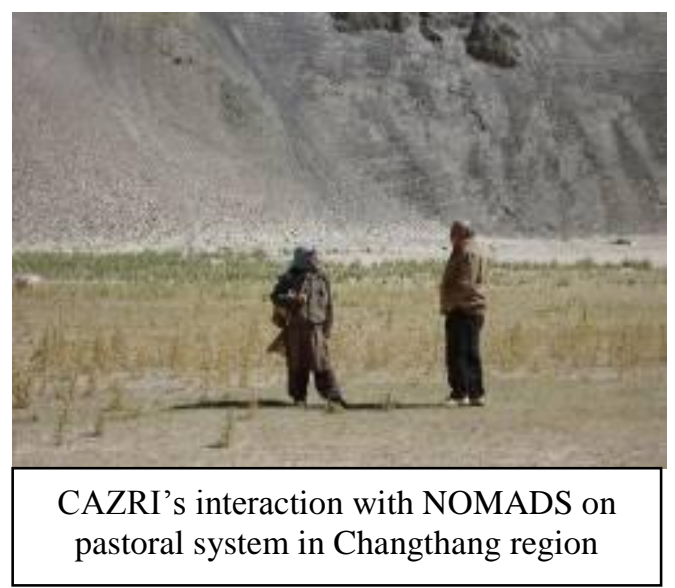


Leh receives scanty rainfall and fed by numerous rivulets that stream down glaciers in this region. Gravity and river canals play an important part in irrigation activities. However, efforts are being made to bring more barren land under cultivation by constructing irrigation canals on the Indus, Shayok and other tributaries. Community approach for distribution of irrigation water is very unique and honest. Every household gets glacier recharge water as irrigation at fixed schedule by informing each other timely. Total irrigated area in the regions stood at 10424 hectares, most of which were covered by Canals and Khuls. With regard to irrigation water security, impact of alarming situation of global warming in cold arid region likely to reduce the amount of snowfall, reducing the water flow in snow-fed rivers during the summer months and WWF (2010) has also reported $21 \%$ decrease glacierized area IHR, with glaciers less than one metre square retreating faster.

Vegetable find important place in the Ladakhi menu with an area 310 ha, producing 7,544 tons of fresh vegetables annually. Although area is very less under vegetables in Leh but every household is growing vegetables in about half or one kanal. Weeding is rarely performed in vegetables. In remote villages where family size is confined to only 2-3 members with old ages, weeding is negligible and it has been recorded that reduction in economic yield of vegetables seem to the tune as reported by Singh et. al., 1993to the tune of 6-82 per cent in potato, $25-30$ per cent in peas, $70-80$ per cent in carrot, 67 per cent in onion, 42-71 per cent in tomato and 61 per cent in cauliflower. Simultaneously, efforts made to apply manure/ fertilizers in vegetables, it can be interpreted that in unweeded vegetable plots, on an average weed extract two times more $\mathrm{N}$ and $\mathrm{Ca}$ and 25 per cent more potassium than the crop (Mallik et al., 1998). As vegetable cultivation is possible only from April to October, and harvesting is done from July to October. On the other hand, with reduced vegetables production may affect the availability of stored vegetables during the critical period for winter months due to subzero temperature. While during winter, only few leafy vegetables find the place to adapt during winter season. Scope of protected agriculture is confined to governmental institutes and farmers with less resources has very small polyhouses which do not suffice their demand during winter season. Then it becomes very critical to store vegetables for their consumption during winter months as the region remain isolated during the harsh winter. Vegetables stored for the winter months form a major source of income for vegetable growers. Womenfolk sell stored vegetable on foot path in the local market.

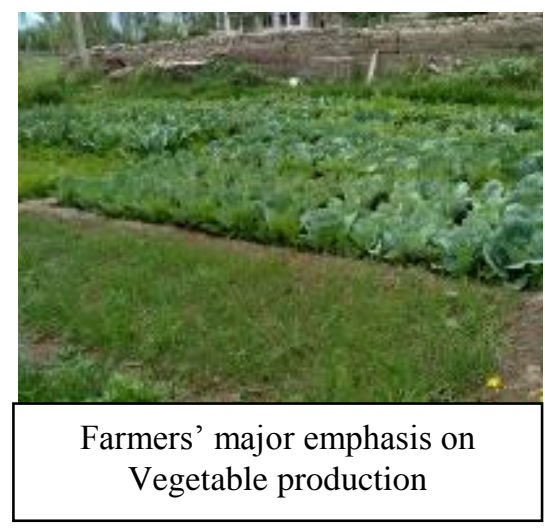




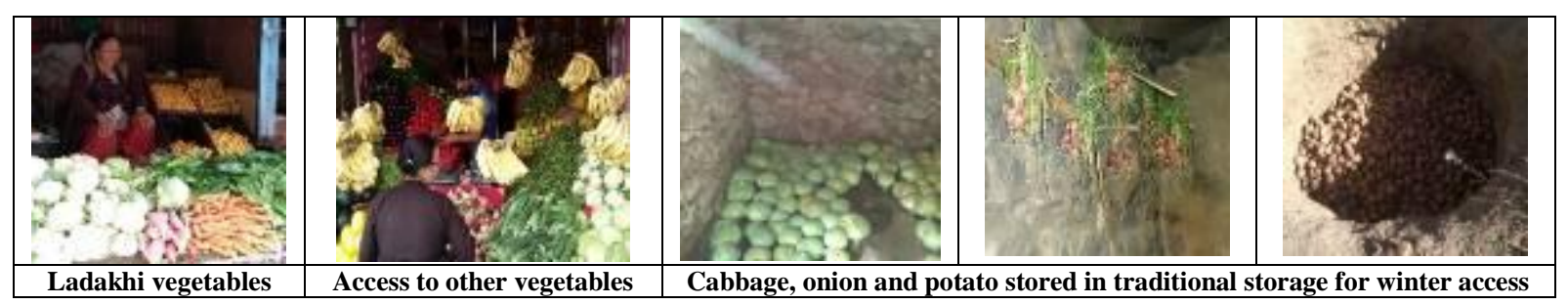

\section{Soil fertility status}

Majority of the soils in Leh and Kargil districts are sandy to sandy loam in texture and medium to medium high (e" $0.75 \%)$ in organic matter with poor water holding capacity. The $\mathrm{pH}$ ranges from 5.65 to 10.12 in Leh and 6.57-9.47 in Kargil. Therefore the majority of soils are alkaline in nature. Nutrients are below the critical level except potassium which is relatively high. On the other hand, irrigation water quality is related to its effect on soils, crops and management practices necessary to overcome problems linked to its quality and can directly affect the crops through toxicity or deficiency. The topography is rugged, undulated with sloppy terrain and prone to erosion (Acharya et al., 2012). Farmers are used to broadcast human excreta $(1.2-1.5 \mathrm{~N}+0.8 \mathrm{P}+0.5 \mathrm{~K})$ as manure to enrich the soil along with partially decomposed farm yard manure. In addition to this, during sowing/ planting, only starter dose of fertiliser like di-ammonium phosphate and muriate of potash are the common one. After that the crops are not taken care off after sowing and immediately get infested with dominant weeds like Agropyron (rampa) or Phragmites (dambu), buck wheat, Chenopodium spp etc. which take away most of the nutrients and crops becomes very weak.
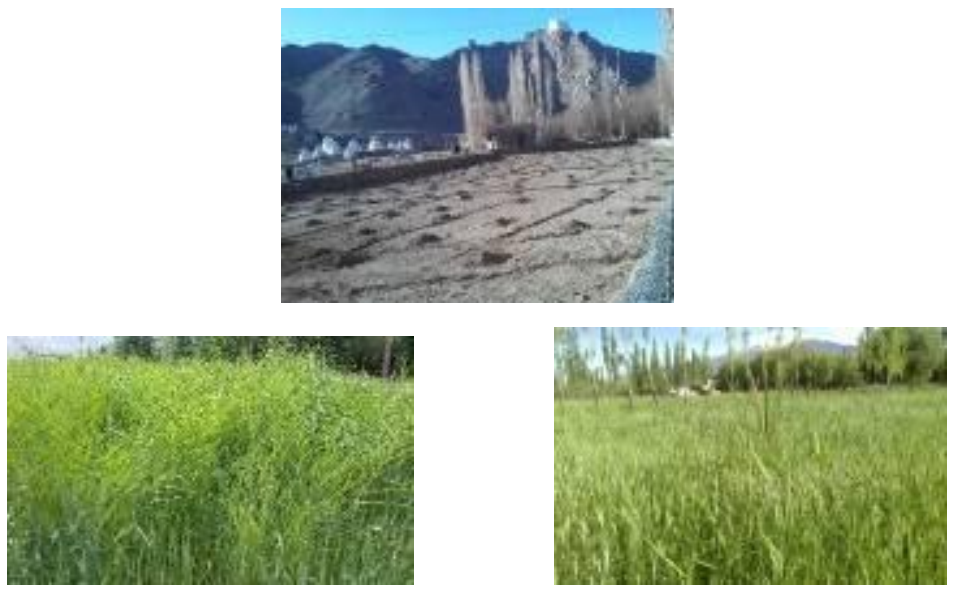

It has been recorded that sea buckthorn- a deciduous shrub, has ability to improve the soil fertility. For the purpose to understand the characteristics of Seabuckthorn (Hippophae rhamnoides L.) plant in cold arid and high altitude habitat, a survey was carried out by Regional Research Station, CAZRI, Leh during 2013 encompassing six different land use patterns. Being a deciduous shrub, it is a multipurpose fast growing species, serving as a measure of biodiversity conservation, and has extensive subterranean rooting system with strong soil binding ability, useful for soil stabilization, river bank control and water retention, soil conservation, medicines, food, wildlife habitat enhancement, farmstead protection, fodder and fuel wood. An 8 to 10year old seabuckthorn forest can fix $180 \mathrm{~kg}$ of 
nitrogen/ha/year. It was recorded that the about 83 per cent of the root nodules are at the depth of $0-15 \mathrm{~cm}$ which support more plant species.

During the survey in different habitats at Leh Valley, following observations on various weed species and related flora were noted associated with varied stages of Hippophae. If planted on the bunds of cultivated area, it may be useful in supporting the crop plant around to be a best example of organic agriculture.

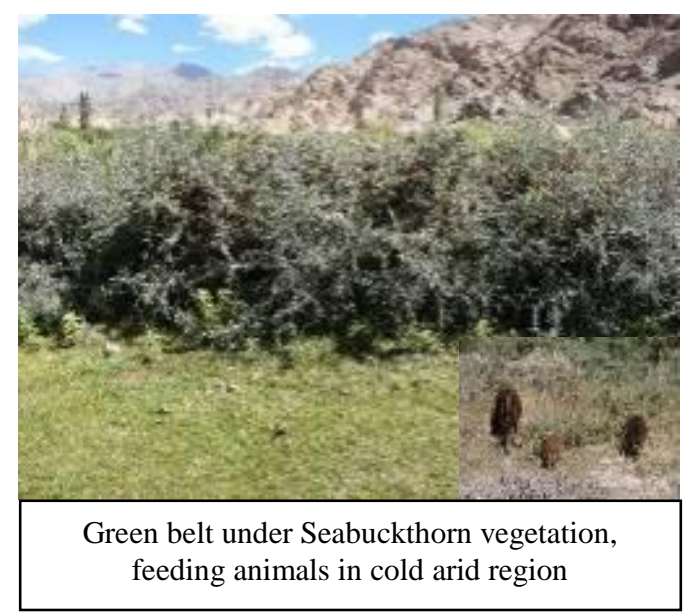

\section{Pest management}

The changing global climate is making direct impact on Indian Himalayan region (IHR). Various pests and diseases are being recorded and new one are also emerging on the crop/ vegetables and tree species. Pest population increases when there is abundance of particular host plant/ tree on which they feed and spread further. New pathological threats have been seen in the last few years on cereals/ vegetable crops under changing climatic conditions. In Ladakh region, increasing menace of insects like codling moth and tent caterpillars in orchards like apple and apricot, respectively, aphids on alfalfa, willows and fruits plants, diseases in barley/ wheat, insect attack in vegetables (cabbage butterfly, and maggots in onion), poplar and salix species have been recorded. It has been noted that the vegetable crops have now become more prone to viral, bacterial and fungal diseases. The situation, however, is entirely different under greenhouse conditions. Under protected conditions, the severity and incidence of insects and diseases like powdery mildew and root rots were found more alarming. It becomes imperative to manage weeds which act as alternate hosts to invite insects and diseases especially in Ladakh where global warming is making direct impact by expanding the range of many diseases. New pests and diseases are likely to emerge as natural ecosystems respond to altered temperature and precipitation profiles because plant disease occurs when three factors combine: a susceptible host, sufficient effective pathogen inoculum and suitable environmental conditions. CAZRI, Jodhpur organized a training on rodent pest management in Chushot village. Management strategies are to be developed in response to natural climate extremes, and may be useful in adopting long-term climate changes. There is need to develop more effective surveillance and experts system for farmers advisory system in the management.

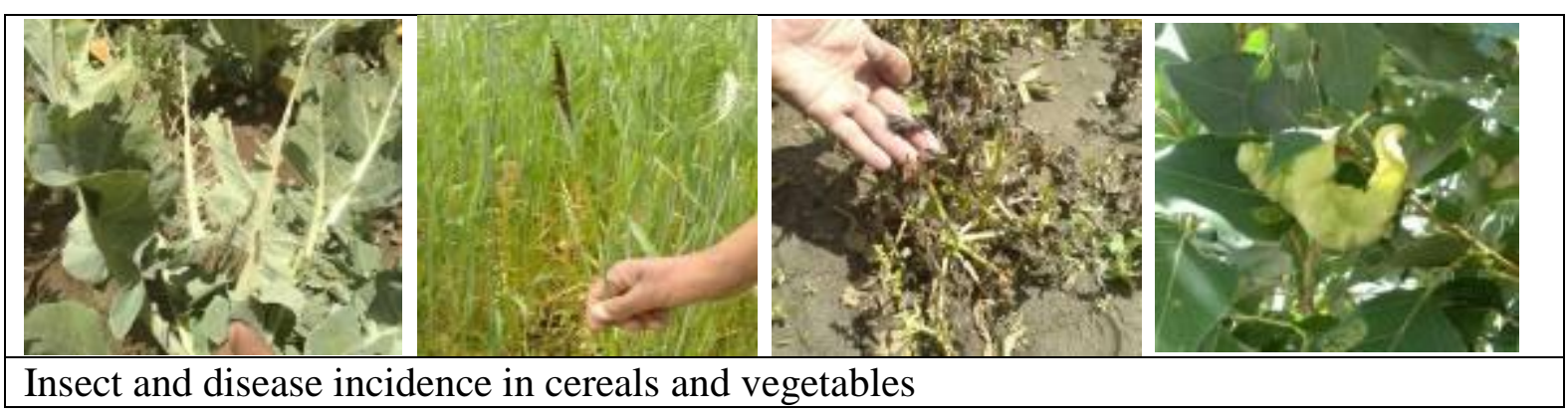




\section{Status of greenhouse cultivation}

Greenhouses with climate controlled devices are very few in the country. On the other hand, Ladakh, being cold, arid, high altitude region of India has a very harsh climate and a short agriculture season. Attempts are being made to popularize solar greenhouses with polyethylene covers in Leh. In early sixties, DIHAR (previously Field Research Laboratory)of DRDO at Leh attempted solar green house vegetable production research and made an outstanding contribution to the extent that at present every household possesses a polyhouse these days in Leh valley. Greenhouse cultivation has been evolved with the objective to create favourable microclimates, which favours the vegetable production. During survey, it was recorded that during harsh winter and declining landholdings, there is an urgent need to encourage farmers by providing timely subsidy for taking up protected agriculture technology in a big way, demand greater attention towards protected agriculture. In addition to this, micro irrigation system has been found best for watering plants in a greenhouse.

Table.1 Production potential of natural leafy vegetables of cold desert Ladakh

\begin{tabular}{|l|l|l|l|}
\hline Vegetables & $\begin{array}{l}\text { Common } \\
\text { name }\end{array}$ & $\begin{array}{l}\text { Leaf yield/ } \\
\text { Cutting } \\
\left(\mathrm{kg} / \mathrm{m}^{2}\right)\end{array}$ & \\
\cline { 1 - 2 } Chenopodium botrys & Sagani & 0.8 & \\
\cline { 1 - 2 } Fagopyrum esculentum & Buckwheat & 0.7 & \\
\cline { 1 - 2 } Lactuca dalichophylla & Khala & 1.4 & \\
\cline { 1 - 2 } Lepidium latifolium & Dittander & 0.7 & \\
\cline { 1 - 2 } Oxyria digya & $\begin{array}{l}\text { Mountain } \\
\text { Sorrel }\end{array}$ & 0.7 & \\
\cline { 1 - 2 } Rumex patientia & Shoma & 1.0 & \\
\hline Urticahyperborea & Zacchaut & 0.9 & Polyhouse \\
\hline
\end{tabular}

(Source- Mishra et al , 2010)

\section{Harvesting trend and productivity}

In West Himalayan cold deserts like Leh, crop harvesting is affected by a sickle used in the upstream direction for maximizing biomass. While in Kargil, barley/ wheat is harvested by uprooting and kept on the road for drying. This indicates that the farmers have very less land holding for sustaining crop productivity. It has also been recorded that higher seeding reduce the number of tillers and during harvesting 8-10 held right near the base, are pushed forward and then cut. Each plant hardly has 3-4 tillers. Thereby reducing total yields. This method of crop harvesting from bottom to top ensures maximum harvest by reducing wastage through easy handling and consequently saving labour.
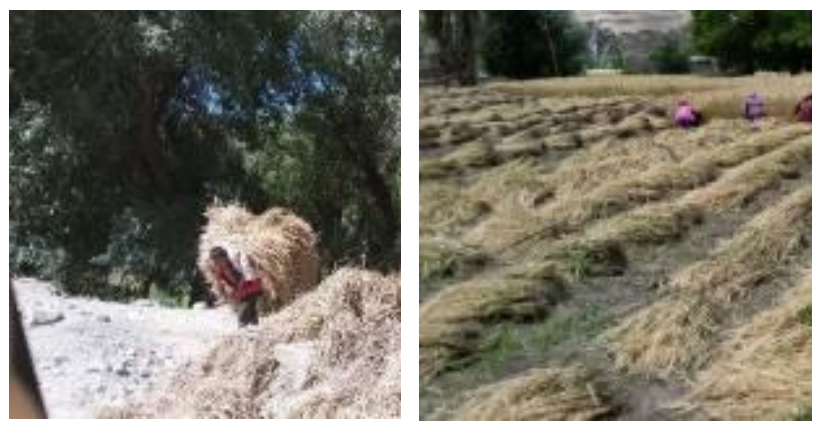

Harvesting pattern in cold arid region 
The total area under wheat and barley in Leh District has remained almost constant for several years. The area under wheat has declined drastically to the tune of 1130 ha i.e. from 3725 ha (1996-97) to 2604 ha (2001-02) to 2595 ha (2011-12) by more than 30 per cent. On the other hand, area under barley (grim) has increased tremendously by 22 per cent i.e. from 3655 ha (1996-97) to 4734 ha (2001-02) to 4488 ha (2011-12) but remained stabilised since 2004. But if it is seen from the data, the area under barley has also declined by 246 ha (LAHDC, 2013).Correspondingly, the productivity of wheat and barley is also declining and far below the potential average yield on per hectare basis. In survey made by CAZRI, it has been recorded that the energy put for producing cereal crops is lesser that energy put in vegetable production in Saboo village. While in Leh district, on an average quantity of food-grain produced is to the tune of 16.5 and $13.8 \mathrm{q} / \mathrm{ha}$, respectively for barley and wheat, which may be attributed to change in food habits and PDS policy. It clearly indicates that farmers are more interested in cash crops instead of cereals. While in case of potato at Leh in almost all the fields where survey have been made, severe infestation of weeds in potato field has been recorded and weed management approach has offered tuber yield to the tune of $16 \mathrm{t} / \mathrm{ha}$ as compared to farmers' method ( $8 \mathrm{t} / \mathrm{ha}$ ). It is assumed that if proper packages of practices are followed along with adequate weed management timely, tuber yield may be enhanced by 50 per cent. Instead traditional farming, if proper packages of practices are followed along with proper weed control, the yield of any crop may be increased significantly at Leh.

Table. 2 Crop productivity of village Saboo

\begin{tabular}{|l|l|l|l|l|}
\hline Crops & \multirow{2}{*}{$\begin{array}{l}\text { Seed Input } \\
(\mathrm{kg} / \mathrm{ha})\end{array}$} & \multicolumn{2}{|l|}{ Yield output (kg/ha) } & Manure \\
\cline { 3 - 4 } & & Grain & Straw & used (kg/ha) \\
\hline Barley & 200 & 528 & 1320 & 200 \\
\hline Wheat & 284 & 820 & 2105 & 242 \\
\hline Pea & 260 & 1350 & 450 & 3960 \\
\hline Tuber (Mainly Potato) & 1720 & 12900 & 2150 & 5340 \\
\hline Other Vegetables* & 2.6 & 612.2 & 896 & 3900 \\
\hline Onion & 2.6 & 342.5 & - & 3512 \\
\hline Alfalfa ( Fresh) & 26.4 & 9784 & & 3321 \\
\hline
\end{tabular}

(Source-Raghuvanshi et al., 2018)

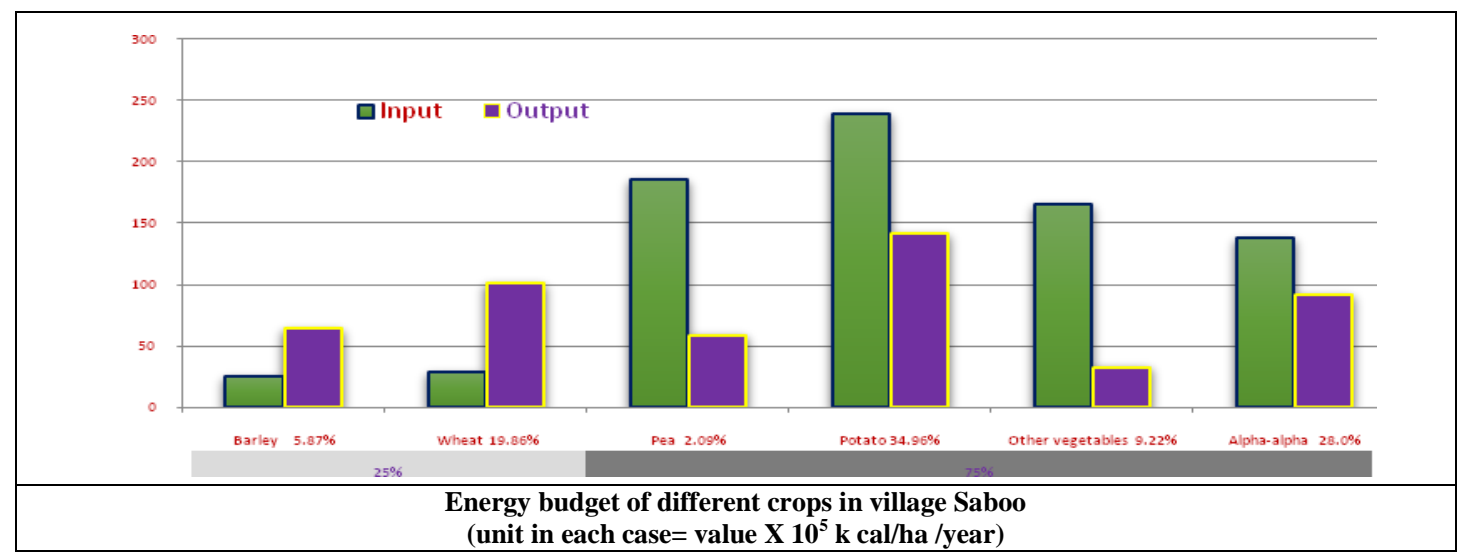


From self-sufficiency to dependence: Present trend

Since last many decades, population of Ladakh (Indian Trans-Himalaya) has led a self-reliantin food-grain production, and pastoralism, i.e. food insecurity level was less than 0.5.The 2008 average yields in Leh district for barley and wheat, reported by the Agriculture Department in Leh on unpublished photocopies, are respectively 21.3 and $17.5 \mathrm{q} / \mathrm{ha}$, while yields for the same products, measured or recorded by scholars and researchers, in different sites, villages or fields in Ladakh, are higher. A conservative aggregate average of $30 \mathrm{q} / \mathrm{ha}$ is accounted for Zanskar valley (Osmaston 1994) and $52.8 \mathrm{q} / \mathrm{ha}$ in Padum village (Mankelow 1999) both in Kargil district. In Khaltsi block of Leh district an average of $32 \mathrm{q} / \mathrm{ha}$ is reported for the Trans-Singe La villages, and $26 \mathrm{q} / \mathrm{ha}$ in Alchi and Saspool villages (Demenge 2007). In Hemis Shupkachan village, during 2010, in a case study of small family managed farm, a yield of $24.7 \mathrm{q} / \mathrm{ha}$ for barley and wheat is recorded (Pelliciardi 2012). All these values can be compared with cereal yield in India which, in 2000, was around $23.4 \mathrm{q} / \mathrm{ha}$ (FAO 2009), in India and Jammu \& Kashmir State, from 2001-02 to 2005-06, were for barley 20.1 and $6.4 \mathrm{q} / \mathrm{ha}$ and for wheat 26.7 and $16.9 \mathrm{q} / \mathrm{ha}$ respectively (DAC 2006). But with the increase of population from about 70000 in 1981 to 145000 in 2011 , is no more selfsufficient in food-grain production and this level of food insecurity is increasing. For overcoming the demand-supply imbalance, huge amount of rice and flour wheat is imported every year by traders, cooperatives and central government under PDS. However to be self-sufficient is an important and debatable issue for this land, especially during harsh winters when roads are closed for about seven months. Filling the gap between the required quantity to feed the growing population and the quantity locally produced can be a difficult task in high altitude cold desert region. There is an immediate need to develop policy and programmatic decision in regard to the local food security problem. During the past 10 years, the quantity of foodgrain imported in this District by PDS has increased from about 56000 quintals, in $2000 / 01$, up to 103000 quintals in2009/10 (61000 rice +42000 wheat flour called "atta"), catering for about 111800 souls through the 130 sale outlets (DSEA 2009). Taking account of all the factors influencing the food system in Leh District, this study has evaluated the dependence on imported food-grain calculating the IDR in $2012,60,2 \%$ which is expected to rise up to $70,3 \%$ by 2025 (Pelliciardi, 2013).

Due to rapid changes in political and socioeconomic structures including ecological conditions, food habits and livelihood security are facing new challenges now-a-days. High mountain regions, which are generally characterised by a peripheral location, limited resource potential, and political marginalisation, are especially exposed to these dynamics.

\section{Feed and fodder}

Existing practice especially in central belt of Leh, fodder Alfalfa (rich in nutrient content) is grown as secondary crop only on the rejected areas. Now it is being treated as main fodder crop, supplemented by wheat and barley straw. During the survey at Thiksey, Stakna and other adjoining villages, it was recorded that crops were sown at much higher seed rate against recommended rate so as to obtain good amount of crop residues along with weeds which are stored and utilized as fodder during winter. Generally weeding is not performed and if grown out of crop fields are realised as fodder. The animals are let loose for grazing the fields and Alfalfa faces huge loss in its total production due to grazing and as well as its early harvest by $3^{\text {rd }}$ week of August to avoid labour load. 

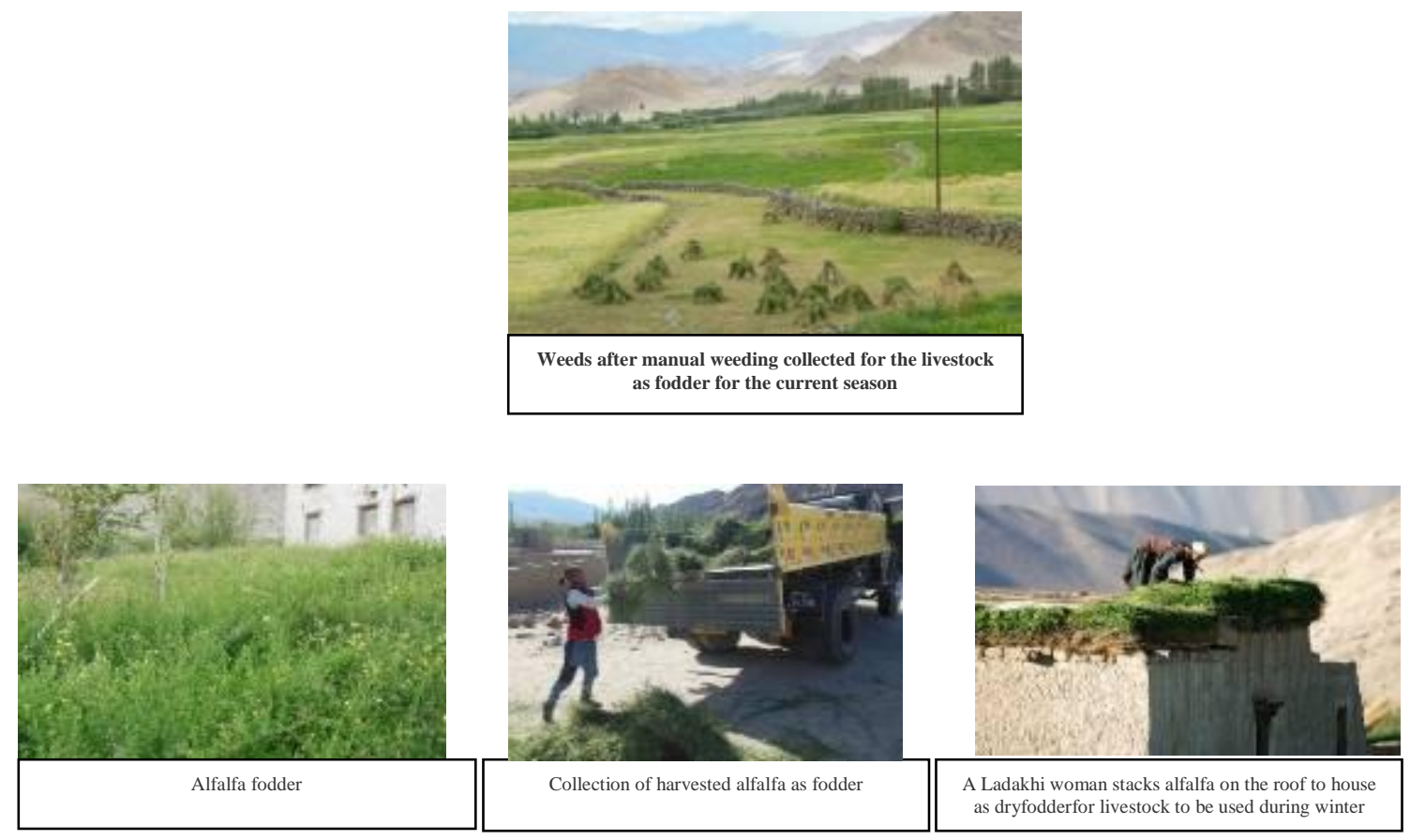

\section{Firewood and cowdung cakes}

Firewood and cow dung cakes are the generally preferred sources of fuel for cooking and space heating, barring requirements in Leh city. Twigs and stems from Salix (21000 $\mathrm{kj} / \mathrm{kg})$, poplar $(9630 \mathrm{kj} / \mathrm{kg})$ and seabuckthorn are used as firewood. The utilization of firewood and cow dung cakes varies as per the accessibility of these resources. In regions where firewood is abundant, cow dung is mainly used as manure. In other regions where households require to buy firewood, or to expend a lot of energy procuring this, cow dung turns to be a substitute fuel for the Chula and bukhari. As it is not possible to collect all the dung that is produced, and not all of it can be converted into dung cakes, this study assumes a collection factor of $60 \%$ and further assumes a utilization factor for dung combustion for each block. There is great scarcity for firewood in Ladakh during winter season. The health damage due to using firewood and cow dung cakes as combustible materials is minimized by providing both the Chula and the bukhari with a chimney that allows the smoke to escape out of the house.

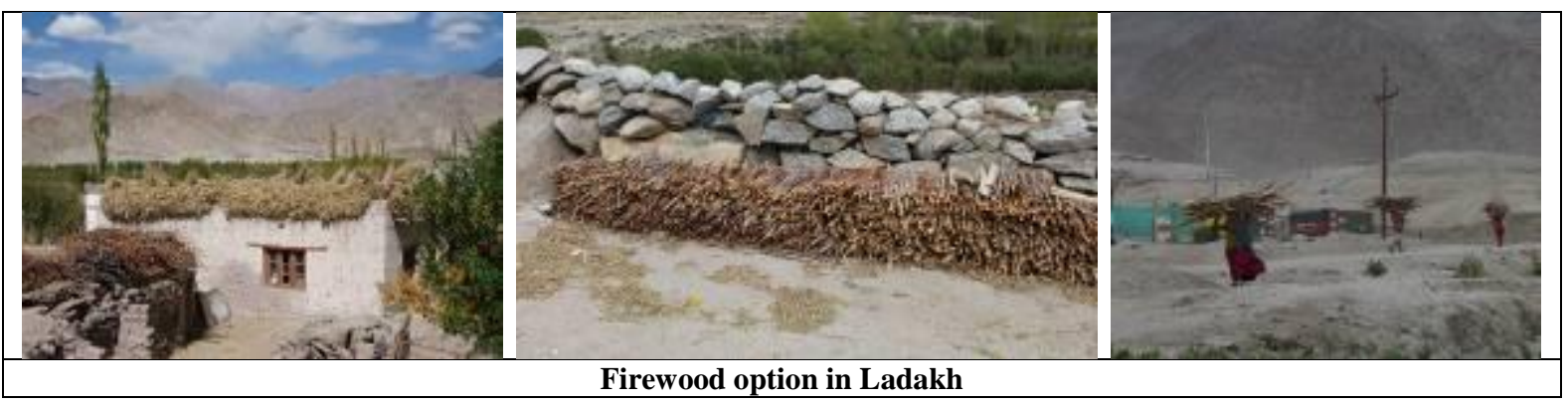

It is concluded that in the light of climate change and traditional farming, land degradation is a major issue facing much of cold desert and is directly affected by land 
use. Adoption of a single, ubiquitous method of farming throughout the Himalaya would be impossible, as the edaphic, topographic and climatic factors vary so greatly and lead to a multitude of crops being grown using varying techniques and for different purposes.

Traditional farming under organic mind-set, subsidized price policies, inadequate technical-know, increased incidence of insectpests and diseases along with severely weed infested crops, reduced manure application, by $60-70$ per cent, depletion and exploitation of natural resources, decline in grazing land by 60 per cent and forest cover, increased vulnerability to soil erosion by all means including flash-floods, inadequate power, low level of farm mechanization and water harvesting, erratic precipitation/ snowfall, poor marketability discourage farmers to intensify their local grain production and stress the diversification of agricultural production toward cash crops by exploiting niche advantages, since one of the District specificity is the relatively good climate in summer. In particular, horticulture (vegetable and fruit). To reduce the dependence from imported food-grain, strategies should be tuned up to revive people's interest in land based economy, building human resources among the local population, promoting land based entrepreneurs to make agro-pastoral livelihoods more remunerative, improving the area under crops and the quantity produced in existing fields; organising a sustained marketing initiative; encouraging a mix of agricultural innovations and traditional methods (LAHDC-Leh 2005). A holistic approach to agroforestry can prioritise and address specific lifestyle factors. Traditional knowledge of climate variability and copingup strategies can be useful in formulating strategies to adapt to the impact of climate change.

It is required to make more efforts to promote advanced agricultural techniques, based on traditional methods of agriculture for achieving agricultural self sufficiency of the region along with diversification of Ladakh agricultural baseto minimise the risk of a single crop failure by introducing high yielding crop varieties, motivating and supporting farmers to adopt the appropriate technologies so as to increase production, promoting the horticultural sector, value addition and marketing of agricultural products, organic farming and seed production, dissemination of technical knowledge of agricultural extension through trainings, workshops and meetings.

\section{References}

Acharya Soman, Singh, Narendra, Katiyar, Anand K., Maurya, S.B. and Shrivastava, R.B. (2012) Improving soil health status of cold desert Ladakh region. DIHAR Bulletin No. 24

DAC (2006). State-wise Normal Area, Production and Yield of Wheat, Average of 2001-02 to 2005-06. Department of Agriculture and Cooperation, Directorate of Economic \& Statistic.

Demenge, J. (2007). Measuring Ecological Footprints of Subsistence Farmer in Ladakh. Paper presented at International Ecological Footprint Confer., Cardiff, Wales

(UK).http://web.mnstate.edu/robertsb/30 7/ANTH\%20307/ecologicalfootprintfar mersladakh.PDF.Accessed 26/05/2009

DSEA (District Statistical \& Evaluation Agency) (2009). Statistical Hand Book 2008-09.

Gyan P. Mishra, Narendra Singh, Hitesh Kumar, and Shashi Bala Singh (2010) Protected Cultivation for Food and Nutritional Security at Ladakh. Defence Science Journal, Vol. 61, No. 2, March 2010, pp. 219-225.

FAO (2009). Statistical Yearbook 2009. Vol. 4. http://www.fao.org/docrep/014/ am079m/am079m00.htm. Accessed 
25/10/2011

LAHDC-L (Ladakh Autonomous Hill Development Council of Leh) (2005). Ladakh 2025 Vision Document. http://leh.nic.in/VISION_DOCUMENT. PDF.

LAHDC (2013) Statistical Hand Book 2013.

Lu R., 1992. Sea buckthorn: a multipurpose plant species for fragile mountains. Intl Centre of Integrated Mountain Development. Katmandu, Nepal.

Mallik RK, Yadav A and Rana MK. 1998. Farmers and parliament, December Issue.

Mankelow, J. S. (1999). The Introduction of Modern Chemical Fertilisers to the Zanskar

Osmaston, H. (1994). The Farming System. In J. Crook \& H. Osmaston (Ed.), Himalayan

Pelliciardi, V. (2012a). Nutrients (N, P, and $\mathrm{K})$ recycling in traditional soil fertility practices in Leh district: a case study at small farm level. International Association for Ladakh Studies, Ladakh Studies, 28, 27-35.

Pelliciardi, Vladimiro (2013) From selfsufficiency to dependence on imported food-grain in Leh District (Ladakh,
Indian Trans-Himalaya). European Journal of Sustainable Development (2013), 2, 3, 109-122- Reference of Pelliciardi cited in the text for the year 2012 is missing.

Raghuvanshi, Mahendra Singh, Jewan Chandra Tewari, Rinchen Dolma, Ayyanadar, Arunachalam and $\mathrm{Om}$ Prakash Yadav (2018) Struggle from Subsistence to Sustainability and Threat to Local Biodiversity under Changing Climate: A Case Study on Ladakh Folk Agriculture. Climate Change and Environmental Sustainability. 5(1): 5965

Rajchal R., 2009. Sea buckthorn Management Guide. Rufford Maurice Laing Foundation, UK and ComForM (Community Based Natural Forest and Tree Manag. in the Himalaya), IoF, Pokhara, Nepal.

Xiaoning, Tu, Baoli, An, Xiufeng, Wen and Jing, Nie (2002) Soil Improvement of Seabuckthorn Plantations and Its Characteristics of the Roots in Loess Plateau. 12th ISCO Conference Beijing 2002: 403-409.

\section{How to cite this article:}

Raghuvanshi, M.S., Ngawang Dorjay, R.K. Singh, B.L. Manjunatha, P.C. Moharana, Enoch Spalbar, Stanzin, Landol, and Anurag Saxena. 2019. Ladakh Traditional Farming: An Approach to Resource Utilization under Changing Climate. Int.J.Curr.Microbiol.App.Sci. 8(09): 654-666. doi: https://doi.org/10.20546/ijcmas.2019.809.079 